\title{
Diversification and Capital Cost of Agricultural Listed Companies-Based on External Financing Analysis
}

\author{
Xue-Xia XU ${ }^{a}$, Ya-Wen LIU ${ }^{\text {b, }}$, Jie JUc, Sun-Lei YANG ${ }^{d}$ \\ Wuhan Textile University, No. 1, Yangguang Road, Jiangxia District, Wuhan, China \\ a872565911@qq.com;b272830418@qq.com;;543925771@qq.com; ${ }^{\text {d } 50495815 @ q q . c o m ~}$ \\ ${ }^{\star}$ Corresponding author
}

Key words: Diversification, Capital cost, Agricultural listed company.

\begin{abstract}
The diversified operation of the agricultural listed companies can reduce the business risk of the enterprises to some extent, so as to have an impact on the capital cost of the enterprises. This paper studies the relationship between diversification and capital cost of agricultural listed companies. Through the empirical research on 412 valid data of agricultural listed companies in Shanghai and Shenzhen from 2005 to 2016. This paper makes an empirical study on the relationship between the diversification of agricultural listed companies and the cost of capital. The results show that the degree of diversification of agricultural listed companies is negatively correlated with the cost of debt, common stock capital and weighted average capital cost. On the basis of this conclusion, this paper provides some basis for our agricultural listed companies to choose the strategy of diversification, and puts forward some suggestions for the development direction of our agricultural listed companies.
\end{abstract}

\section{Foreword}

Agriculture is the foundation of the national economy and its importance is self-evident. As a leading enterprise in China, the development of agricultural listed companies has an important impact on the sustainable development of agriculture and the stable operation of the national economy.With the recovery of the Chinese economy, the internal competitive pressure in the Chinese market has gradually increased. However, the total scale of the agricultural listed companies in China is relatively small, and the profitability of the listed agricultural companies is on the low side. The ability to resist risks is low. higher degree of diversification. The characteristics of the industry with better solvency[1]. Therefore, the strategy of diversification has gradually been attached importance to and implemented. The diversification strategy of agricultural listed companies in our country mostly presents the trend of compound diversification, and adopts the equity financing method, because of the agricultural listed companies under the diversification strategy. Shareholders see no advantage over other competitors specialising in a particular industry, in which case the return on investment demanded by investors increases and the cost of capital increases.

At present, the research of diversification strategy is mainly carried out from two angles, motivation research and management consequence study, which focuses on the influence of diversification on the enterprise value at home and abroad. By studying the relationship between the diversification of agricultural listed companies and financial risks, Zhang Huaqing and Zhang Min found that the diversification of agricultural listed companies into non-related business financial risk[2]. Su Xin(2017)and Liu Haolong studied the relationship between diversification and corporate performance from the perspective of executive ownership, and found that the relationship between product diversification and corporate performance is not a simple linear relationship, but an inverted "U" relationship[3].

As to the relationship between diversification and capital cost, foreign scholars think that diversification can reduce the cost of capital. After studying the relationship between diversification strategy and corporate structure, Barton and Gordon found that the degree of diversification was positively correlated with leverage (debt level) and negatively correlated with risk. That is, 
diversification will spread the risk, reducing the cost of capital[4]. The domestic literature research has the opposite view to this. QianYisheng and Wang Junxi based on the data of A shares listed in 2011 and 2012, empirical research shows that the degree of diversification is significantly positively correlated with the cost of equity financing[5]. Zhang Hong, Chen Jiawei and Li Linjun(2015) studied 59 listed real estate companies in Shanghai and Shenzhen from 2003 to 13 and found that the degree of diversification was negatively correlated with the cost of common stock capital, and positively correlated with the cost of debt capital. It is negatively correlated with the proportion of debt to capital, and positively correlated with the weighted average cost of capital[6].

From the above review, we can see that there is no uniform conclusion on the relationship between diversification and capital cost. Most of the researches on agricultural listed companies focus on the relationship between diversification and equity costs, and rarely on debt financing costs. This paper distinguishes most literatures from the relationship between diversification and capital cost, and selects agricultural listed companies to make the analysis more targeted.

\section{Research Hypothesis}

According to the principal-agent theory, the distrust between shareholders and agents and the conflicts of interests between large shareholders and minority shareholders will lead to dissatisfaction of some shareholders and increase the expected return of shareholders. As a result of the company's equity financing costs increased. With the increase of the diversification of the company, the limited staff cannot meet all the management, the agent increases , the friction between the shareholders in different industries increases, and the strange degree increases, which further increases the cost of equity financing. At the same time, considering the theory of pecking order, combined with China's national conditions, investors are more willing to choose equity financing, so we can appropriately reduce their own demand for return, resulting in a lower cost of equity financing.

Therefore, two competitive hypotheses are proposed:

Hypothesis 1a: under other conditions, the degree of diversification of agricultural listed companies is positively correlated with the cost of equity financing.

Hypothesis 1b: limit other conditions, the degree of diversification of agricultural listed companies is negatively correlated with the cost of equity financing.

According to the theory of financing order, when enterprises implement diversification strategy, when debt financing is in the position of oversupply, excessive choice of equity financing will lead to the reduction of debt financing costs. Considering Markowitz's theory of risk diversification and investment diversification, the portfolio of the diversification strategy of agricultural listed companies is more inclined to choose the portfolio with lower correlation, and according to the risk and return positive correlation. It shows that when the overall risk is reduced, the return required by the investors is reduced, that is, the higher the degree of the agricultural listed company is, the lower the cost of equity financing and debt financing is at the same time. Thus affects the average weighted capital cost, causes it to reduce.

The following two hypotheses are therefore proposed:

Hypothesis 2 : Under other conditions, the diversification of agricultural listed companies is negatively correlated with the debt cost .

Hypothesis 3: under the restriction of other conditions, the degree of diversification of agricultural listed companies is negatively correlated with the average weighted capital cost.

\section{Research Design}

\section{Sample Selection}

This paper through the CHOICE database, from 2005 - 2016 in Shanghai and Shenzhen 46 agricultural listed companies at the end of the year a total of 412 financial data, excluding individual data is not complete, and the development of agricultural listed companies to switch or 
liquidation, taking into account the agricultural listed companies to set up time is longer the more obvious degree of diversification, select data from the beginning of 2005 the selection of agricultural listed companies, industry standards in 2015 Chinese Securities Regulatory Commission issued the "guidelines on the industry classification of Listed Companies in the basis. Empirical data from the Wande database, Cathay Pacific CSMAR economic and financial database and Rex database choice database, using SPSS 20.0 for data analysis.

\section{Variable Definition}

\section{Explained Variable}

The explained variable in this paper is the cost of capital(Coc), which includes the cost of debt and the cost of equity financing, considering that the weighted average cost of capital can reflect the capital status of the company more synthetically. It is considered as an explanatory variable.

(1) In calculating the cost of equity financing $(\mathrm{Ke})$, this paper uses CAPM model, the model is as follows:

$\mathrm{Ke}=\mathrm{R} \mathrm{f}+\beta *(\mathrm{R} \mathrm{m}-\mathrm{R} \mathrm{f})$

$\mathrm{Rf}$ Bank free rate of return

$B$ investment $\beta$ coefficient

$\mathrm{Rm}$ Expected return on market investment

In this paper, the data selection:

Ef Selecting the deposit rate of the 3-year bank as the risk-free return rate 3.9\%

$\beta$ Selecting the risk factors of agricultural listed companies to reflect the risk state of agricultural listed companies

$\mathrm{Rm}$ The return on investment in the stock market from 2005 to 2016 is chosen as the return on market investment of agricultural listed companies based on the annual rate of return on reinvestment per share of A shares in the same period of Shanghai and Shenzhen

(2) In terms of calculating the cost of debt financing(Kd), according to Zhang Hong's (2015)calculation method, the cost of short-term debt is calculated according to the average interest rate of the bank's 1-year loan in the current year(one year divided into 6 months and 6 months to 1 year). The cost of long-term debt is calculated on the basis of the three to five years of the current year's medium and long-term loan rates. In the case of loan rate adjustment, the short-term loan rate and the medium and long-term loan interest rate are weighted by the number of days.

(3) The formula for measuring the weighted average cost of capital(WACC) is as follows:

$\mathrm{WACC}=\mathrm{E} * \mathrm{~K} \mathrm{e} /(\mathrm{D} \mathrm{l}+\mathrm{D} \mathrm{s}+\mathrm{E})+\mathrm{D} \mathrm{l} * \mathrm{~K} \mathrm{dl}(1-\mathrm{t}) /(\mathrm{D} \mathrm{l}+\mathrm{D} \mathrm{s}+\mathrm{E})+\mathrm{D} \mathrm{s} * \mathrm{~K}$ ds $(1-\mathrm{t}) /(\mathrm{D} \mathrm{l}+\mathrm{D} \mathrm{s}+\mathrm{E})$

Among them, $\mathrm{E}$ is equity, $\mathrm{K}$ e is the cost of equity financing(data calculated using the above (CAPM), $\mathrm{D} \mathrm{l}$ is a long-term debt, $\mathrm{K} \mathrm{dl}$ is long-term debt financing cost, $\mathrm{D} \mathrm{s}$ is short-term debt, $\mathrm{K}$ sl is the cost of short - term debt financing, $t$ is tax rate for enterprise(25\%).

\section{Explanatory Variable}

Explain the degree of diversification of variables(Div). The number of industries $\mathrm{N}$ (the number of industries involved in the main business) and the Hillman index of income(HHI) are taken as the measures of diversification.

\section{Controlled Variable}

In the light of our country ' s economic development , scholars in our country use the following variables when studying the influence of a variable on capital cost : company size(Size), asset-liability ratio(Lev), current ratio(Liq), asset turnover(Tur), mercantile rate of return(ROCE), Industry risk coefficient $(\beta)$, the prospect of the company(Pe), Tangible assets secured value(D) etc. The above control variables will also be used in this paper .

\section{Model Construction}

According to the research variables and control variables, the model between diversification strategy and capital cost of agricultural listed companies is as follows: 
$\mathrm{Ke}=\beta 0+\beta 1$ Size $+\beta 2 \mathrm{Lev}+\beta 3$ Liquid $+\beta 4$ Turnover $+\beta 5 \mathrm{ROE}+\beta 6 \mathrm{Pe}+\beta 7 \mathrm{D}+\beta 8 \mathrm{HHI}+\beta 9 \mathrm{~N}+\mathrm{a}$

$\mathrm{Kd}=\beta 0+\beta 1$ Size $+\beta 2 \mathrm{Lev}+\beta 3$ Liquid $+\beta 4$ Turnover $+\beta 5 \mathrm{ROE}+\beta 6 \mathrm{Pe}+\beta 7 \mathrm{D}+\beta 8 \mathrm{HHI}+\beta 9 \mathrm{~N}+\mathrm{a}$

$\mathrm{WACC}=\beta 0+\beta 1$ Size $+\beta 2 \mathrm{Lev}+\beta 3 \mathrm{Liquid}+\beta 4$ Turnover $+\beta 5 \mathrm{ROE}+\beta 6 \mathrm{Pe}+\beta 7 \mathrm{D}+\beta 8 \mathrm{HHI}+\beta 9 \mathrm{~N}+\mathrm{a}$

The coefficients of the model are assumed to be constant when using the data. $\beta 0$ constants, $\beta 1-9$ coefficient, a error. If the $\beta 8-9$ corresponding to Ke in the model 1 is positive , the hypothesis $1 \mathrm{a}$ is assumed to be established, whereas the hypothesis $1 \mathrm{~b}$ is established . If the opposite is significant or not, other situations need to be considered. If the opposite occurs, only one is significant and the tendency of comprehensive consideration is significant. The analysis of model $2 \mathrm{KD}$ corresponding to $\beta 8$-9 and model 3 is as above.

\section{Empirical Analysis}

\section{Descriptive Statistics}

The weighted average capital of the cost of capital is -0.457 , the maximum is 50.346 , and the minimum is -192.672 . The average value of equity financing cost is -1.351 , the maximum value is 90.7, the minimum value is -240.81 .The average value of long-term debt financing cost is 0.252 , the maximum value is 7.48 . The minimum value is -5.95 . The cost of short-term debt financing is 0.436 , the maximum value is 6.8 , and the minimum is -5 . The average value of risk coefficient $\beta$ is 0.2419 , the maximum value is 3.58, the minimum value is -2401.65. The $\mathrm{N}$ mean value is 5.95 , the maximum value is 7 , and the minimum value is 1 . At the same time, the average value of $\mathrm{HHI}$, the maximum value and the minimum value are $0.476,1.07$ and 0.007 , respectively. These data show that the diversification degree is different among the agricultural listed companies, and the risk level among the diversified industries is different, and the difference of the capital cost is large .

Table 1. Descriptive analysis

\begin{tabular}{|l|l|l|l|l|l|}
\hline Variable & $\mathrm{N}$ & Minimum & Maximum & Mean Value & Standard Deviation \\
\hline WACC & 412 & -192.6718 & 50.3456 & -0.4573 & 10.5570 \\
\hline HHI & 412 & 0 & 1.0677 & 0.4760 & 0.3861 \\
\hline $\mathrm{N}$ & 412 & 1 & 7 & 5.95 & 0.430 \\
\hline ke & 412 & -240.8131 & 90.0726 & -1.3517 & 16.0638 \\
\hline kdl & 412 & -5.95 & 7.48 & .2520 & 3.5943 \\
\hline kds & 412 & -5.0 & 6.8 & .436 & 3.1328 \\
\hline$\beta$ & 412 & -241.65 & 3.58 & .2419 & 10.33240 \\
\hline Size & 412 & 16.9265 & 23.6381 & 20.4414 & 1.1736 \\
\hline Lev & 412 & 0.02812 & 3.0564 & 0.4433 & 0.2529 \\
\hline Size & 412 & 149179220.2 & 13694137608 & 2943951092 & 2604020937 \\
\hline$\beta$ & 412 & 0.0544 & 0.1725 & 1.013 & 0.240 \\
\hline Liq & 412 & 0.1319 & 35.0203 & 2.3849 & 3.4454 \\
\hline Tur & 412 & 0.0011 & 2.0480 & 0.5735 & 0.3636 \\
\hline Pe & 412 & -1.0000 & 1497.1560 & 3.2612 & 67.9815 \\
\hline D & 412 & 0.0040 & 0.9518 & 0.4682 & 0.1958 \\
\hline
\end{tabular}

\section{Correlation Analysis}

There is a negative correlation between the diversification variable HHI and the equity financing cost ke at the level of 0.05 , and the initial refusal to hypothesis $1 \mathrm{a}$ accepts the hypothesis $1 \mathrm{~b}$ : to limit the other conditions. The degree of diversification of agricultural listed companies is negatively related to the cost of equity financing; The diversification represents a negative correlation between the variable $\mathrm{N}$ and the debt financing cost $\mathrm{Kd}$ at 0.01 level , and the initial acceptance hypothesis 2 : Under other conditions, the diversification degree of the agricultural listed companies is negatively correlated with the debt cost ; There is no significant level of diversification $\mathrm{HHI}$ and $\mathrm{N}$ and weighted average capital cost (WACC), but we reject hypothesis 3 : 
under other conditions, the degree of diversification of agricultural listed companies is negatively correlated with the average weighted capital cost.

Table 2. Diversification and capital cost of agricultural listed companies

\begin{tabular}{|l|l|l|l|l|l|l|l|l|l|l|l|l|l|}
\hline & ke & kdl & kds & WACC & HHI & N & $\beta$ & Size & Lev & Liq & Tur & Pe & D \\
\hline ke & 1 & & & & & & & & & & & & \\
\hline kdl & -0.023 & 1 & & & & & & & & & & & \\
\hline kds & -0.023 & $1.000^{* *}$ & 1 & & & & & & & & & & \\
\hline WACC & $0.915^{* *}$ & $0.112^{*}$ & $0.112^{*}$ & 1 & & & & & & & & & \\
\hline HHI & $-0.107^{*}$ & $0.100^{*}$ & $0.100^{*}$ & -0.059 & 1 & & & & & & & & \\
\hline N & 0.013 & $-0.198^{* *}$ & $-0.198^{* *}$ & 0.008 & $-0.092^{*}$ & 1 & & & & & & & \\
\hline$\beta$ & $0.731^{* *}$ & 0.017 & 0.017 & $0.895^{* *}$ & -0.030 & -0.010 & 1 & & & & & & \\
\hline Size & $-0.103^{*}$ & -0.044 & -0.044 & $-0.143^{* *}$ & 0.009 & 0.050 & $-0.107^{*}$ & 1 & & & & & \\
\hline Lev & 0.006 & 0.057 & 0.057 & 0.014 & -0.058 & $-0.474^{* *}$ & 0.024 & -0.002 & 1 & & & & \\
\hline Liq & 0.016 & 0.018 & 0.018 & -0.001 & $0.108^{*}$ & 0.032 & 0.009 & -0.048 & $-0.413^{* *}$ & 1 & & & \\
\hline Tur & -0.082 & $-0.216^{* *}$ & $-0.216^{* *}$ & $-0.135^{* *}$ & $-0.197^{* *}$ & $0.121^{* *}$ & $-0.123^{* *}$ & $0.111^{*}$ & -0.072 & $-0.150^{* *}$ & 1 & & \\
\hline Pe & 0.005 & 0.068 & 0.066 & 0.009 & 0.060 & $-0.320^{* *}$ & 0.010 & -0.007 & 0.001 & 0.000 & -0.035 & 1 & \\
\hline D & -0.052 & -0.068 & -0.068 & -0.016 & -0.045 & $0.184^{* *}$ & -0.026 & $-0.297^{* *}$ & -0.063 & -0.082 & $-0.113^{*}$ & -0.038 & 1 \\
\hline
\end{tabular}

**. There was significant correlation at level 0.01 (bilateral).

*. There is a significant correlation between the 0.05 level (bilateral).

\section{Multiple Regression Analysis}

Table 3 Table of Regression Coefficient

\begin{tabular}{|l|l|l|l|l|}
\hline Variable & Model 1 & Model 2(kdl) & Model 2(kds) & Model 3 \\
\hline Constant & $43.645^{* *}$ & $11.008^{* *}$ & $9.800^{* *}$ & $35.030^{* *}$ \\
(quantity) & $(2.055)$ & $(2.397)$ & $(2.448)$ & $(2.522)$ \\
\hline \multirow{2}{*}{$\mathrm{N}$} & 1.939 & $-1.595^{* * *}$ & $-1.387^{* * *}$ & 1.607 \\
& $(1.115)$ & $(-3.342)$ & $(-3.333)$ & $(1.166)$ \\
\hline \multirow{2}{*}{ HHI } & $-6.235^{* * *}$ & $-850^{*}$ & $0.739^{*}$ & $-2.702^{*}$ \\
& $(-2.622)$ & $(1.658)$ & $(1.654)$ & $(-1.737)$ \\
\hline \multirow{2}{*}{ SIZE } & $-2.310^{* * *}$ & 0.066 & 0.057 & $-1.831^{* * *}$ \\
& $(-2.732)$ & $(0.374)$ & $(0.371)$ & $(-3.310)$ \\
\hline \multirow{2}{*}{ lev } & 0.525 & $-1.611^{*}$ & $-1.399^{*}$ & 0.073 \\
& $(0.120)$ & $(-1.664)$ & $(-1.657)$ & $(0.025)$ \\
\hline \multirow{2}{*}{ liq } & -0.025 & -.063 & -.055 & -.107 \\
& $(-0.099)$ & $(-1.089)$ & $(-1.081)$ & $(-0.641)$ \\
\hline \multirow{2}{*}{ tur } & $-5.676^{* *}$ & $-2.822^{* * *}$ & $-2.460^{* * *}$ & $-5.326^{* * *}$ \\
\hline \multirow{2}{*}{ pe } & $(-2.120)$ & $(-5.169)$ & $(-5.168)$ & $(-3.042)$ \\
\hline \multirow{2}{*}{$\mathrm{D}$} & 0.005 & 0.000 & 0.000 & 0.004 \\
& $(0.461)$ & $(-0.087)$ & $(-0.128)$ & $(0.485)$ \\
\hline
\end{tabular}

When the Herfindahl index is used as the explanatory variable, model one (equity financing cost) and model three (weighted average capital cost) have negative coefficients. It shows that the degree of diversification has a negative correlation with the cost of equity financing, the weighted average capital cost, and the coefficient of diversification index is significant at the level of $1 \%$ or $5 \%$. The previous hypothesis $1 \mathrm{~b}$ passes, while hypothesis $1 \mathrm{a}$ does not, taking into account that the correlation coefficient of the weighted average capital cost is not significant, rejects hypothesis 3 . The coefficient of model two is positive and significant at the level of $5 \%$, which indicates that the higher the degree of diversification, the higher the cost of debt financing, therefore, refusing to hypothesis 2 . 
Analyze the number of industries directly as the explanatory variables: $\mathrm{N}$ is significantly lower than the explained variable debt financing cost at the level of $1 \%$, and the coefficient is negative, which is inconsistent with the conclusion of the above analysis from the perspective of HHI, considering that the significance is higher, and tends to be more likely to accept hypothesis 2 .

The turnover rate and tangible collateral value of assets in the three model are reflected in different levels was significant, and the coefficient is negative, that agricultural listed companies in China in the process of implementing diversification strategy, debt levels significantly increased, combined with China's national conditions into consideration, the test results from the side to accept the hypothesis of 2,3.

\section{Conclusion and Proposition}

This paper makes an empirical study on 412 valid data of agricultural listed companies in Shanghai and Shenzhen from 2005 to 2016. The results show that the diversification of agricultural listed companies is negatively related to the cost of capital financing. On the basis of this conclusion, this paper puts forward some suggestions on the development direction of China's agricultural listed companies:

(1) Agricultural listed companies should be cautious about diversification Strategy

For the diversification of the cost of capital and agricultural listed companies performance development, agricultural listed companies can not be blindly optimistic attitude, should consider the development of the company in the state, using some analysis means. Establish your own company's core strengths, take internal advantages to seize external opportunities.

(2) Choosing a diversified business strategy suitable for yourself

Most of the agricultural listed companies that have achieved better performance combine vertical with the center and take the original industry as the core to develop upstream and downstream. For a well funded agricultural listed company, we choose to invest in assets with different earnings. This will help to save costs, increase efficiency and enhance company performance.

(3) The agricultural listed companies that have implemented the diversification strategy should look at the development of the company

The long-term strategy means a lot of uncertainty, at the same time means that the strategy may have short-term deceptive, agricultural listed companies should always examine its development status, timely response to their own problems. Consider whether diversification strategies need to be adjusted.

\section{References}

[1] Xia Xianli, Zhang Xinglong, RenJianhua. The influence of diversification on the performance of Agricultural listed companies[J]. Finance and Accounting Monthly,2011(21):28-30.(In Chinese)

[2] Zhang Huaqing, Zhang Min. An empirical Analysis on the Financial risk of Agricultural listed companies' diversification[J]. Finance and Accounting Monthly,2014(12):18-19.(In Chinese)

[3] Su Xin, Liu Haolong. The influence of diversification on Enterprise Performance-The regulatory role of executive stock ownership[J].economic issue,2017(4):100-107.(In Chinese)

[4] Barton S L,Gordon P J. Corporate Strategy and Capital Structure[J]. Strategic Management Journal,1988 (9):623 -632.

[5] QianYisheng, Wang Junxi.An empirical study on diversification and the cost of Equity financing[J].new accounting,2014(11):3-7.(In Chinese)

[6] Zhang Hong, ChenJiawei, LiLinjun. Research on the relationship between diversification Strategy and Capital cost of listed Real Estate companies[J].economic issue,2015(10):1—6.(In Chinese) 